\title{
Antioxidant Activity and Anti-wrinkle Effects of Aceriphyllum rossii Leaf Ethanol Extract
}

\author{
Bi Gyeon Ha', Min Ah Park', Chae Myoung Lee ${ }^{2}$ and Young Chul Kim ${ }^{1}$ \\ ${ }^{1}$ Major in Public Health, Faculty of Food \& Health Sciences, Keimyung University, Daegu, Korea \\ ${ }^{2}$ Department of Beauty Coordination, Keimyung College University, Daegu, Korea
}

(Received November 11, 2015; Revised December 15, 2015; Accepted December 16, 2015)

\begin{abstract}
We evaluated the antioxidant activity and anti-wrinkle effects of Aceriphyllum rossii leaf ethanol extract (ARLEE) in vitro using human dermal fibroblasts. The total polyphenol and flavonoid contents of ARLEE were 578.6 and $206.3 \mathrm{mg} / \mathrm{g}$, respectively. At a concentration of $250 \mu \mathrm{g} / \mathrm{mL}$, the electron-donating ability of ARLEE was $87.1 \%$. In comparison with the vehicle, ARLEE treatment at $100 \mu \mathrm{g} / \mathrm{mL}$ significantly increased type I procollagen synthesis $(p<0.01)$ by $50.7 \%$. In vitro ARLEE treatment $(10 \mathrm{mg} / \mathrm{mL})$ inhibited collagenase and elastase activity by $97.1 \%$ and $99.2 \%$, respectively. Compared with the control, ascorbic acid treatment at $100 \mu \mathrm{g} / \mathrm{mL}$ significantly decreased matrix metalloproteinase (MMP)-1 protein expression $(p<0.01)$ by $37.0 \%$. ARLEE treatment at $50 \mu \mathrm{g} / \mathrm{mL}$ significantly decreased MMP-1 protein expression $(p<0.01)$ by $46.1 \%$. Ascorbic acid and ARLEE treatments at $100 \mu \mathrm{g} / \mathrm{mL}$ significantly decreased MMP-1 mRNA expression $(p<0.01)$ by $26.1 \%$ and $36.1 \%$, respectively. From these results, we conclude that ARLEE has excellent antioxidant activity and even better anti-wrinkle effects than ascorbic acid in human dermal fibroblasts. These results suggest that ARLEE could be used in functional cosmetics for the prevention or alleviation of skin wrinkles induced by ultraviolet rays.
\end{abstract}

Key words: Aceriphyllum rossii, Antioxidant activity, Collagenase activity, MMP-1, Type I procollagen

\section{INTRODUCTION}

Skin aging is commonly associated with increased wrinkling, sagging, and skin laxity (1). Chronic sun exposure especially causes photoaging of human skin (2). Ultraviolet (UV) light is well known to cause various types of skin damage that lead to premature aging. Collagen accounts for roughly $90 \%$ of the extracellular matrix (ECM) in human dermis; type I collagen accounts for at least $80 \%$ of the total collagen, and alterations in its structure have been considered to be a primary cause of skin aging and wrinkle formation (3).

Matrix metalloproteinases (MMPs) are a family of zincdependent endoproteinases that are capable of degrading almost all of the components of the ECM. They have been classified in more than 20 species (4), and as neutral endo-

Correspondence to: Young Chul Kim, Major in Public Health, Faculty of Food \& Health Sciences, Keimyung University, 1095 Dalgubeol-daero, Daegu 42601, Korea

E-mail: yckim@kmu.ac.kr

This is an Open-Access article distributed under the terms of the Creative Commons Attribution Non-Commercial License (http:// creativecommons.org/licenses/by-nc/3.0) which permits unrestricted non-commercial use, distribution, and reproduction in any medium, provided the original work is properly cited. peptidases, are produced by various cell types such as fibroblasts, macrophages, endothelial cells, and keratinocytes (5). The expression of MMPs in UV-irradiated fibroblasts is known to be initiated by reactive oxygen species (ROS) (6). MMPs play a pivotal role in dynamic remodeling of the ECM, including degradation of ECM proteins. Ascorbic acid has been shown to increase ECM synthesis as well as assist in the maintenance of ECM proteins, while transforming growth factor (TGF)- $\beta 1$ may induce the synthesis of type I collagen in the fibrin-based matrix as well as other natural matrices (7). Among the MMPs, MMP-1 plays a major role in the enhanced degradation of dermal type I collagen during UV-induced skin photoaging (8). TGF- $\beta$ is a potent growth factor that stimulates the production of collagen types I, II, III, IV, V, and VII, elastin, and fibronectin (9), but suppresses the synthesis of MMP-1 (10).

Aceriphyllum rossii Engler (family Saxifragaceae), a species endemic to Korea, is a perennial herb that grows on damp rocks along valleys, usually to a height of $30 \mathrm{~cm}$. The main chemical constituents of $A$. rossii are pentacyclic triterpenoids (11). In previous studies, anticarcinogenic (12), antioxidant, anti-inflammatory, antiobestic, antidiabetic (13), and antimicrobial (14) activities of $A$. rossii have been reported. However, its inhibitory efficacy on skin wrinkling 
has been poorly investigated.

In this study, the antioxidant activity and inhibitory effects of $A$. rossii leaf ethanol extract (ARLEE) against skin wrinkling were investigated. The anti-wrinkle effects of ARLEE were evaluated with regard to collagen synthesis, collagenase and elastase activity, and MMP-1 mRNA and protein expression in human dermal fibroblasts.

\section{MATERIALS AND METHODS}

Reagents and apparatus. 1,1-Diphenyl-2-picryl hydrazyl (DPPH), tannic acid, Folin-Ciocalteu's phenol reagent, 3-(4,5-dimethyl-thiazol-2-yl)-2,5-diphenyl-tetrazolium bromide (MTT), elastase from porcine pancreas, N-succinyl(L-Ala) ${ }_{3}$ - $p$-nitroanilide, collagenase, and 4-phenylazobenzyloxy-carbonyl-Pro-Leu-Gly-Pro-D-Arg were purchased from Sigma-Aldrich (St. Louis, MO, USA). Dulbecco's modified Eagle's medium (DMEM), Roswell Park Memorial Institute (RPMI)-1640 medium, fetal bovine serum (FBS), and penicillin/streptomycin (P/S) were purchased from Lonza Company (Cascade, USA).

An inverted microscope (CKX41, Olympus, Japan) was used for observing cell growth, and a $\mathrm{CO}_{2}$ incubator (MCO17AC, SANYO electric, Japan) was used for cell culture.

Preparation of Aceriphyllum rossii ethanol extracts. The leaf, stem, and root of $A$. rossii were collected from Yanggu, Gangwon, Korea. Pulverized samples (50 g) were put into a flask and extracted with $500 \mathrm{~mL}$ of $80 \%$ ethanol 3 times for $24 \mathrm{hr}$ each at $25^{\circ} \mathrm{C}$. The extract was filtered with filter papers and concentrated using a rotary vacuum evaporator (BÜCHI R-205, BÜCHI Labortechnik AG, Switzerland) followed by lyophilization (yield: leaf $22.8 \%$, stem $12.0 \%$, and root $8.6 \%$ ).

Total polyphenol content. The Folin-Denis assay (15) was performed to determine the total polyphenol content of ARLEE, $A$. rossii stem ethanol extract (ARSEE), and $A$. rossii root ethanol extract (ARREE). One milliliter each of ARLEE, ARSEE, ARREE, and Folin reagent was placed in a test tube and allowed to stand for $3 \mathrm{~min}$ before adding $1 \mathrm{~mL}$ of $10 \% \mathrm{Na}_{2} \mathrm{CO}_{3}$ and shaking vigorously. The tubes were incubated for $1 \mathrm{hr}$ at room temperature before measuring the absorbance at $725 \mathrm{~nm}$. A standard curve was prepared using tannic acid.

Total flavonoid content. The total flavonoid content of ARLEE, ARSEE, and ARREE was determined using a modified Davies method (16). ARLEE, ARSEE, and ARREE $(100 \mu \mathrm{L})$ were placed in a test tube before adding $1 \mathrm{~mL}$ of diethylene glycol reagent and $100 \mu \mathrm{L}$ of $1 \mathrm{~N}$ $\mathrm{NaOH}$. The mixture was shaken vigorously and incubated at $37^{\circ} \mathrm{C}$ for $1 \mathrm{hr}$ before measuring the absorbance at $420 \mathrm{~nm}$. A standard curve was prepared using rutin.
Electron donating ability. Electron-donating ability was evaluated as previously described (17). One milliliter of ARLEE, ARSEE, and ARREE was dissolved in distilled water at 250,500 , or $1,000 \mu \mathrm{g} / \mathrm{mL}$ and placed in a test tube before adding $4 \mathrm{~mL}$ of $0.4 \mathrm{mM}$ DPPH. The mixture was shaken vigorously and incubated for $10 \mathrm{sec}$ at $60^{\circ} \mathrm{C}$ before measuring the absorbance at $525 \mathrm{~nm}$. Ascorbic acid was used as the positive control.

Collagenase activity inhibition. Calcium chloride (4 $\mathrm{mM}$ ) dissolved in 0.1 M Tris-HCl buffer ( $\mathrm{pH} 7.5$ ) was used as the final buffer with substrate 4-phenylazo-benzyloxycarbonyl-Pro-Leu-Gly-Pro-D-Arg $(0.15 \mathrm{mg} / \mathrm{mL})$ dissolved in the buffer. The substrate solution $(250 \mu \mathrm{L})$ and $100 \mu \mathrm{L}$ of an adequate concentration of the sample were injected into the tube. Clostridium histolyticum collagenase was dissolved in the final buffer to achieve a concentration of $0.2 \mathrm{mg} / \mathrm{mL}$, and $150 \mu \mathrm{L}$ of it was added. After incubation at $37^{\circ} \mathrm{C}$ for $30 \mathrm{~min}$, the reaction was stopped by adding citric acid $(6 \%)$. The reaction mixture was separated by adding ethyl acetate. The absorbance of the supernatant was measured at $324 \mathrm{~nm}$, with ascorbic acid as the positive control.

Elastase activity inhibition. In order to evaluate the inhibition of elastase activity, the amount of released $p$ nitroaniline, which is hydrolyzed from the substrate $\mathrm{N}$-succinyl-(L-Ala) ${ }_{3}-p$-nitroanilide by elastase, was read with an absorbance at $410 \mathrm{~nm}$. In brief, $2.9 \mathrm{mM} \mathrm{N}$-succinyl-(LAla) $)_{3}-p$-nitroanilide was prepared in $100 \mathrm{mM}$ Tris- $\mathrm{HCl}$ buffer ( $\mathrm{pH} 8.0)$, and this solution was added to the stock sample. Each sample solution was diluted to a final concentration of $1.25,2.5,5$, or $10 \mathrm{mg} / \mathrm{mL}$. The solutions were mixed thoroughly by tapping before an elastase $(0.2$ unit $/ \mathrm{mL})$ stock solution was added. Solutions were incubated for 10 $\min$ at $37^{\circ} \mathrm{C}$, and the absorbance was measured at $410 \mathrm{~nm}$.

Cell culture and morphological observation. The human dermal fibroblasts used in this study were obtained from Amore Pacific Company (Korea). The cells were grown in DMEM supplemented with $10 \% \mathrm{FBS}$ and $1 \% \mathrm{P} / \mathrm{S}$ in a humidified $5 \% \mathrm{CO}_{2}$ atmosphere at $37^{\circ} \mathrm{C}$ for $72 \mathrm{hr}$. Human dermal fibroblasts were treated with $25 \sim 200 \mu \mathrm{g} / \mathrm{mL}$ ARLEE, and the morphology of the cells observed following $48 \mathrm{hr}$ of growth at $37^{\circ} \mathrm{C}$ and $5 \% \mathrm{CO}_{2}$. Following incubation, the medium was changed and the cells observed under an inverted microscope.

UVA irradiation and sample treatment. Human dermal fibroblasts were cultivated in a culture dish until approximately $80 \%$ confluency at $200 \mathrm{~nm}$. After removing the medium, the cells were washed with PBS. The samples were treated to the cells $\left(1.5 \times 10^{5}\right.$ cells $\left./ \mathrm{mL}\right)$ in the DMEM without FBS before irradiation with $6.3 \mathrm{~J} / \mathrm{cm}^{2}$ UVA. This was followed by cultivation for $24 \mathrm{hr}$ and quantification of 
MMP-1 expression.

Cell viability assay. Cell viability was assessed using the MTT assay to determine the maximum permissible level (MPL) of ascorbic acid and ARLEE in human dermal fibroblasts. Human dermal fibroblasts were placed in a 96well plate $\left(1 \times 10^{4}\right.$ cells/well $)$ and incubated in a humidified $5 \% \quad \mathrm{CO}_{2}$ atmosphere at $37^{\circ} \mathrm{C}$ for $24 \mathrm{hr}$. ARLEE $(200 \mu \mathrm{L})$ was diluted with phenol red-free DMEM (PRFDMEM) to concentrations of $25,50,100$, and $200 \mu \mathrm{g} / \mathrm{mL}$ before addition to the wells; the plate was then incubated for another $48 \mathrm{hr}$. MTT $(0.5 \mathrm{mg} / \mathrm{mL})$ was added to each well and the cells were incubated for a further $3 \mathrm{hr}$. The plate was centrifuged at $1,000 \mathrm{rpm}$ for $10 \mathrm{~min}$, the supernatant was removed, and $200 \mu \mathrm{L}$ of DMSO was added to each well. After dissolving the cells for 15 min with a plateshaker, the absorbance at $540 \mathrm{~nm}$ was measured with an ELISA reader (680, Bio-Rad Laboratories, Japan).

Type I procollagen synthesis. Human dermal fibroblasts were treated with ARLEE at concentrations of 12.5, 25,50 , and $100 \mu \mathrm{g} / \mathrm{mL}$, and the supernatants were removed and analyzed with an EIA kit (Takara, Japan). The absorbance at $450 \mathrm{~nm}$ was used to calculate the type I procollagen protein yield as described (18), with TGF- $\beta 1(5 \mathrm{ng} / \mathrm{mL})$ used as the positive control.

Human dermal fibroblasts were stabilized in DMEM containing $10 \%$ FBS and 1\% P/S (DMEM-FBS-P/S), and incubated in a humidified $5 \% \mathrm{CO}_{2}$ atmosphere at $37^{\circ} \mathrm{C}$ for $24 \mathrm{hr}$. The cells were harvested and divided into the wells of a 6well plate in a $500 \mu \mathrm{L}$ volume with $0.7 \times 10^{5}$ cells/well and incubated for $24 \mathrm{hr}$. After removing the medium, the cells were washed twice with PBS, and $1 \mathrm{~mL}$ of PRF-DMEM with $1 \% \mathrm{P} / \mathrm{S}$ was added before incubating for a further $24 \mathrm{hr}$. The cells were washed with PBS, and $3 \mathrm{~mL}$ of PRFDMEM containing ARLEE at concentrations of 12.5, 25, 50 , and $100 \mu \mathrm{g} / \mathrm{mL}$ was added. The cells were incubated for $24 \mathrm{hr}$, and the supernatants were obtained by centrifugation for $10 \mathrm{~min}$ at $12,000 \mathrm{rpm}$ for use as the sample for procollagen protein quantitative analysis. The antibody-peroxidaseconjugate solution $(100 \mu \mathrm{L})$ was placed into the wells of a 96-well EIA kit and $20 \mu \mathrm{L}$ of the 4-fold diluted samples were added. The kit was wrapped in foil and incubated at $37^{\circ} \mathrm{C}$ for $3 \mathrm{hr}$.
The cells were washed 4 times with PBS; $100 \mu \mathrm{L}$ of the substrate solution was added, and the foil-wrapped kit was incubated at room temperature for $15 \mathrm{~min}$. The stop solution $\left(100 \mu \mathrm{L}\right.$ of $\left.1 \mathrm{~N} \mathrm{H}_{2} \mathrm{SO}_{4}\right)$ was added, and absorbance at $450 \mathrm{~nm}$ was measured 3 times with an ELISA reader. The procollagen protein yield was separated from the protein content as described (19), and quantified with bovine serum albumin (BSA) standards. Cell lysis buffer $(80 \mu \mathrm{L}$; CelLytic $^{\mathrm{TM}}$ B Cell Lysis Reagent, Sigma, USA) was added to the plate; the plate was frozen $\left(-20^{\circ} \mathrm{C}\right)$ and thawed 3 times before removing the mixture. The protein content of $1 / 10$ dilution of the freeze-thawed mixture was quantified using the BSA standard curve.

Western blotting. Cell lysates treated with 12.5, 25, 50 , and $100 \mu \mathrm{g} / \mathrm{mL}$ ARLEE were prepared by sonicating human dermal fibroblasts in $0.1 \mathrm{M}$ Tris- $\mathrm{HCl}(\mathrm{pH} 7.2)$ buffer containing $1 \%$ Nonidet $\mathrm{P}-40,0.01 \%$ SDS, and a protease inhibitor cocktail (Roche, Mannheim, Germany). The protein concentration of cell lysates was measured using the Pierce Protein Assay Kit (Pierce Biotechnology, Inc., Rockford, USA), with BSA as the standard. Equal amounts of protein $(10 \mu \mathrm{g})$ were loaded into each lane, and separated by electrophoresis on a $10 \%$ polyacrylamide gel. Following transblotting onto nitrocellulose, membranes were incubated with ab 137332 (1:1,000, anti-MMP-1; Abcam, UK) and anti-rabbit IgG (1:1,000; Santa Cruz Boitechnology, USA). Immunoreactive bands were detected by chemiluminescence using electrochemical luminescence reagents (Amersham, Bucks, UK). Band intensity was measured using the Image $\mathrm{J}$ program (NIH, Bethesda, USA), with $\beta$ actin as an internal control.

Reverse transcription-polymerase chain reaction (RT$P C R)$. The total RNA from the human dermal fibroblasts was extracted with $1 \mathrm{~mL}$ of TRIzol (Invitrogen, CA) per the manufacturer instructions, and $5 \mu \mathrm{g}$ samples were reversetranscribed in $40-\mu \mathrm{L}$ of a reaction mixture containing $8 \mu \mathrm{L}$ of $5 \times$ Molony murine leukemia virus reverse transcriptase (M-MLV RT) buffer, $3 \mu \mathrm{L}$ of dNTPs $(10 \mathrm{mM}), 0.45 \mu \mathrm{L}$ of RNasein $(40 \mathrm{U} / \mu \mathrm{L}), 0.3 \mu \mathrm{L}$ of M-MLV reverse transcriptase $(200 \mathrm{U} / \mu \mathrm{L}$; Promega, USA), and $1.5 \mu \mathrm{L}$ of oligo dT $(50 \mathrm{pM} / \mu \mathrm{L}$; Bioneer, Korea). Single-stranded cDNA was amplified by PCR using $4 \mu \mathrm{L}$ of $5 \times$ green Go Taq Flexi

Table 1. The primer sequences for target genes used for PCR in human dermal fibroblasts

\begin{tabular}{lllc}
\hline \hline Genes & & Primers & Expected size $(\mathrm{bp})^{1)}$ \\
\hline \multirow{2}{*}{ MMP-1 $^{2)}$} & Forward $\left(5^{\prime} \rightarrow 3\right)$ & CGACTCTAGAAACACAAGAG & 237 \\
& Reverse $\left(5^{\prime} \rightarrow 3\right)$ & AAAGTTAGCTTACTGTCACACGTT & 248 \\
\multirow{2}{*}{$\beta$-actin } & Forward $\left(5^{\prime} \rightarrow 3^{\prime}\right)$ & ACCGTGAAAAGATGACCCAG & 2 \\
& Reverse $\left(5^{\prime} \rightarrow 3^{\prime}\right)$ & TACGGATGTCAACGTCACAC & 2 \\
\hline
\end{tabular}

\footnotetext{
1)bp: basepair.

${ }^{2)}$ MMP-1: matrix metalloproteinase-1.
} 
buffer, $0.4 \mu \mathrm{L}$ of dNTPs $(10 \mathrm{mM}), 0.1 \mu \mathrm{L}$ Taq polymerase (5 $\mathrm{U} / \mu \mathrm{L}), 1.2 \mu \mathrm{L}$ of $\mathrm{MgCl}_{2}(25 \mathrm{mM}$; Promega, USA), and $0.4 \mu \mathrm{L}$ each of $(20 \mathrm{pM} / \mu \mathrm{L})$ specific sense and anti-sense primers for MMP- 1 or $\beta$-actin. The PCR primer sequences are described in Table 1. The PCR conditions were as follows: 28 cycles of $94^{\circ} \mathrm{C}$ for $60 \mathrm{sec}, 50^{\circ} \mathrm{C}$ for $60 \mathrm{sec}$, and $72^{\circ} \mathrm{C}$ for $60 \mathrm{sec}$. The PCR products were run on a $1.2 \%$ agarose gel, with $\beta$-actin acting as an internal control to evaluate the relative expression of MMP-1.

Statistical analysis. Statistical analysis was performed using SPSS 21.0 (SPSS Inc., Chicago, IL, USA). Differences between the groups were assessed using either one-way analysis of variance (ANOVA) followed by Duncan's multiple range test for a post-hoc comparison or Student's $t$-test. $\mathrm{P}$ values $<0.05$ were considered to be statistically significant.

\section{RESULTS}

Antioxidant activity. The total polyphenol contents of ARLEE, ARSEE, and ARREE were 578.6, 1.3, and 71.2 $\mathrm{mg} / \mathrm{g}$, respectively, according to the tannic acid standard curve (Fig. 1). The total flavonoid contents of ARLEE, ARSEE, and ARREE were 206.3, 82.3, and $63.5 \mathrm{mg} / \mathrm{g}$, respectively, according to the rutin standard curve (Fig. 1). Electron-donating abilities of ARLEE, ARSEE, and ARREE at $1,000 \mu \mathrm{g} / \mathrm{mL}$ were $88.7 \%, 85.1 \%$, and $86.5 \%$, respectively. These values were similar to that of the control ascorbic acid at the same concentration (90.2\%) (Fig. 2).

Collagenase and elastase activity inhibition. The collagenase inhibitory efficacy of ARLEE at $10 \mathrm{mg} / \mathrm{mL}$ was

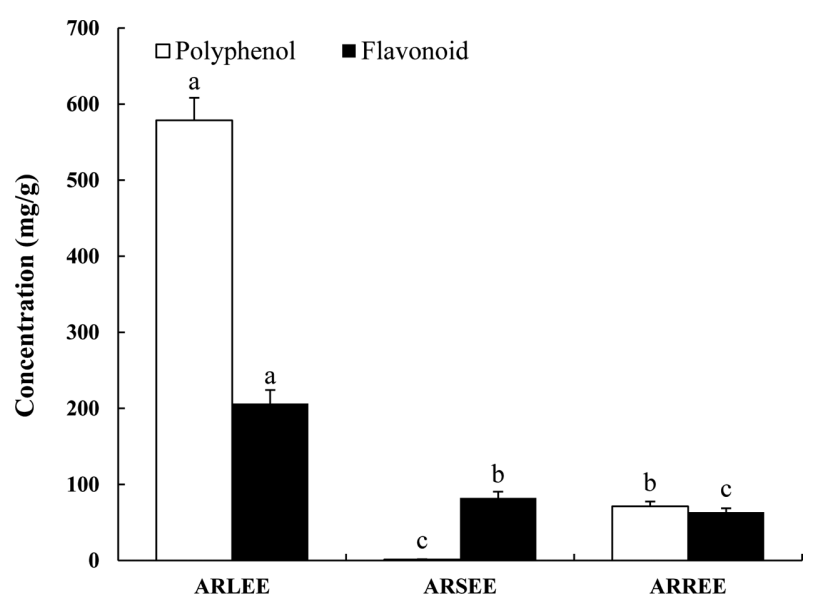

Fig. 1. Total polyphenol and flavonoid contents of Aceriphyllum rossii ethanol extracts. Values represent the mean \pm SD of three independent measurements. ${ }^{a, b, c}$ Values with different superscripts indicate significant differences $(p<0.05)$ for each polyphenol or flavonoid content, by ANOVA and Duncan's multiple range tests.
$97.1 \%$. This value was similar to that of the control, ascorbic acid, at the same concentration (100\%) (Fig. 3). ARLEE elastase inhibitory efficacy at $10 \mathrm{mg} / \mathrm{mL}$ was $99.2 \%$. This value was significantly $(p<0.001)$ higher than that of the control at the same concentration (51.6\%) (Fig. 4).

Cell viability and morphological observation. Ascorbic acid treatment at concentrations of 100 and $200 \mu \mathrm{g} / \mathrm{mL}$

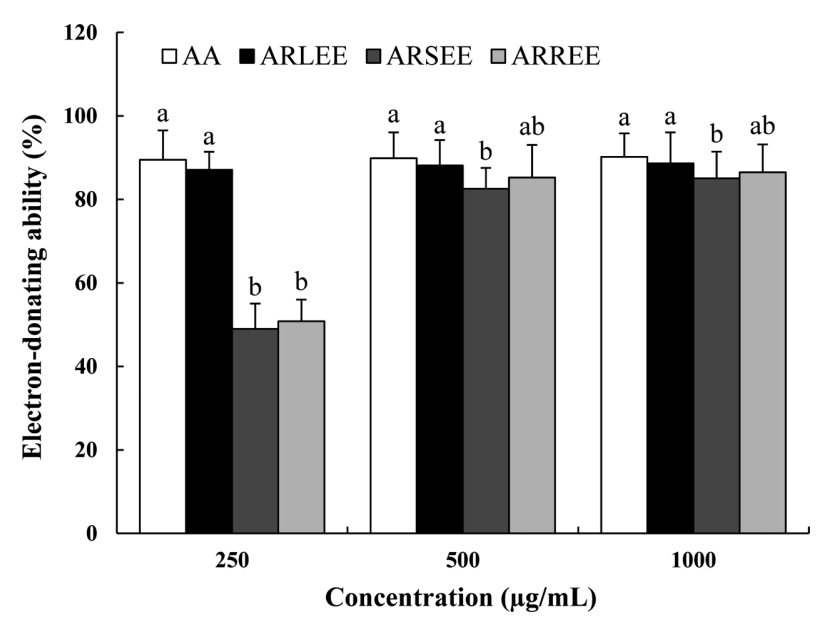

Fig. 2. Electron-donating ability of Aceriphyllum rossii ethanol extracts relative to the control ascorbic acid at the indicated concentrations. Each substance was evaluated on its ability to provide electrons to the free radical DPPH. AA: ascorbic acid, ARLEE: $A$. rossii leaf ethanol extract, ARSEE: $A$. rossii stem ethanol extract, ARREE: A. rossii root ethanol extract. Values represent the mean $\pm S D$ of three independent measurements. ${ }^{a, b}$ Values with different superscripts indicate significant differences $(p<0.05)$ for each given concentration, by ANOVA and Duncan's multiple range tests.

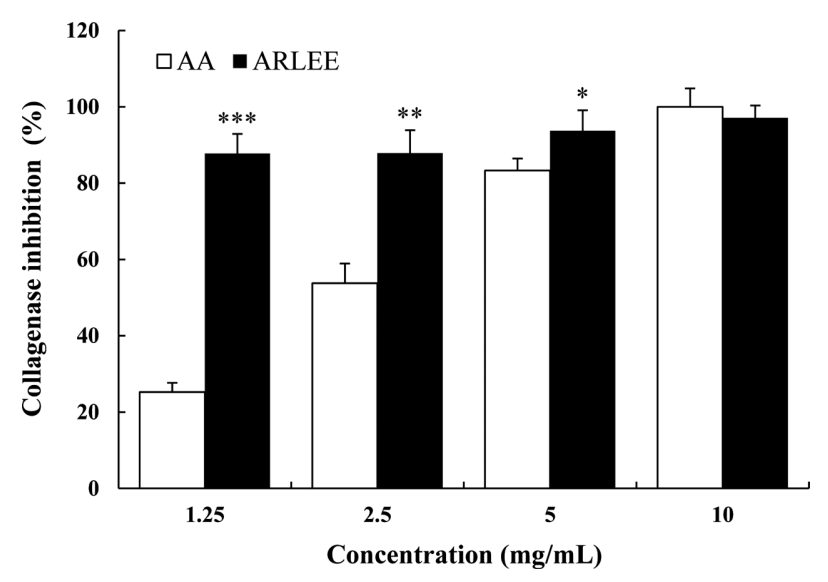

Fig. 3. Collagenase activity inhibition of ARLEE relative to the control ascorbic acid. AA: ascorbic acid, ARLEE: A. rossii leaf ethanol extract. Values are the mean $\pm S D$ of three independent measurements. The value with an asterisk is significantly different from the AA group by Student's $t$-test $\left({ }^{*} ; p<0.05\right.$, ${ }^{* *} ; p<$ $\left.0.01,{ }^{* * *} ; p<0.001\right)$. 


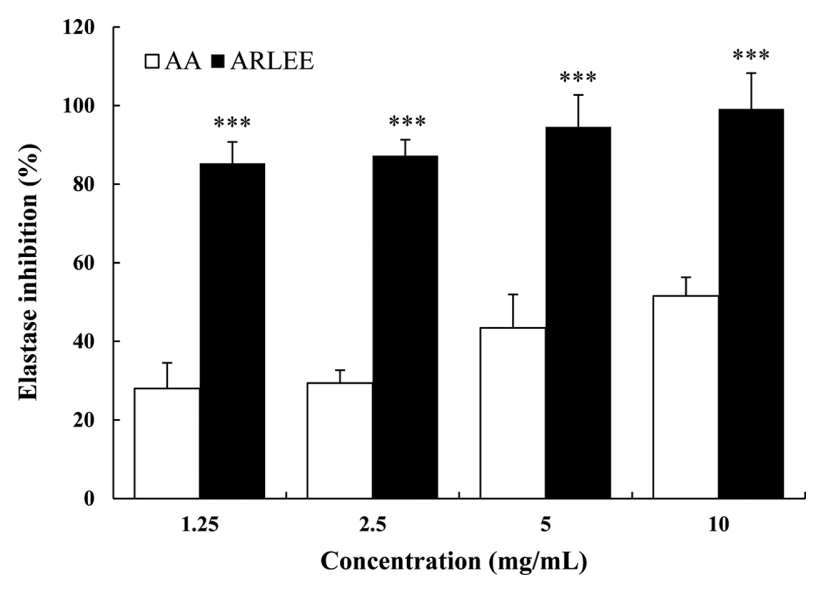

Fig. 4. Elastase activity inhibition of ARLEE relative to the control ascorbic acid. AA: ascorbic acid, ARLEE: $A$. rossii leaf ethanol extract. Values are the mean $\pm S D$ of three independent measurements. The value with an asterisk is significantly different from the AA group by Student's t-test $\left.{ }^{* * * ;} p<0.001\right)$.

reduced cell viability by $6.5 \%$ and $30.2 \%$, respectively, compared to vehicle-treated cells. Thus, the MPL for ascorbic acid application to human dermal fibroblasts was $100 \mu \mathrm{g} / \mathrm{mL}$ (data not shown). ARLEE treatment at concentrations of 100 and $200 \mu \mathrm{g} / \mathrm{mL}$ reduced cell viability by $6.0 \%$ and $31.6 \%$, respectively, compared to vehicle-treated cells, exhibiting an MPL of $100 \mu \mathrm{g} / \mathrm{mL}$ (data not shown). Fibroblasts treated with low or intermediate concentrations of ascorbic acid maintained the flat, spindle-like shape observed in vehicle-treated cells. However, at a concentration of $200 \mu \mathrm{g} / \mathrm{mL}$, the cells had an irregular or

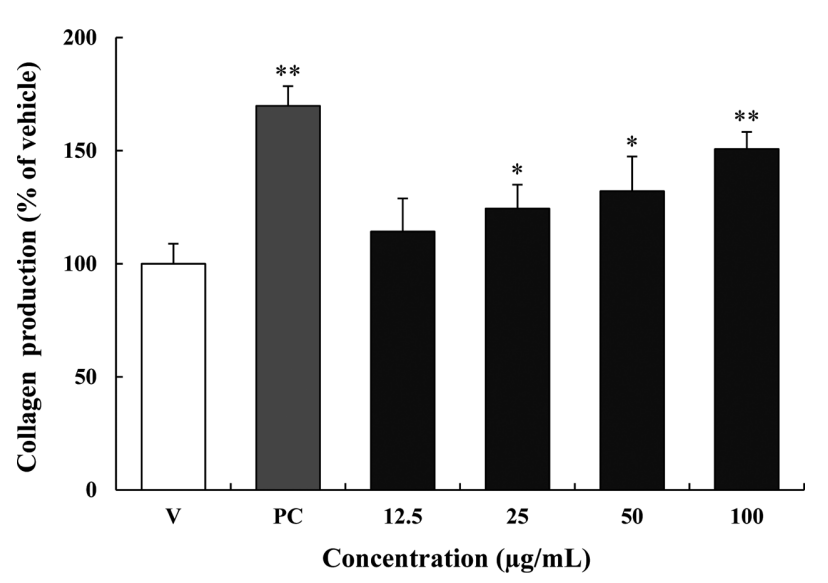

Fig. 5. Effect of ARLEE on collagen production in human dermal fibroblasts. Cells were treated with the vehicle (V), $5 \mathrm{ng} / \mathrm{mL}$ TGF- $\beta 1$ (PC), or A. rossii leaf ethanol extract (ARLEE) at the indicated concentrations, and the production of procollagen was measured by ELISA. Values are the mean \pm SD of three independent measurements. The value with an asterisk is significantly different from the vehicle group by Student's $t$-test $(* ; p<0.05$, ${ }^{* *} ; p<0.01$ ). rounded shape, and cell density was decreased. In contrast, fibroblasts treated with $25 \sim 200 \mu \mathrm{g} / \mathrm{mL}$ ARLEE maintained the flat, spindle-like shape observed in vehicletreated cells.

Effect of ARLEE on type I procollagen synthesis. In comparison with the vehicle treatment, ARLEE treatment at $12.5,25,50$, and $100 \mu \mathrm{g} / \mathrm{mL}$ increased collagen production by $14.2 \%, 24.4 \%(p<0.05), 32.1 \%(p<0.05)$, and $50.7 \%$ $(p<0.01)$, respectively, in a dose-dependent manner (Fig. 5).

Effect of ARLEE on MMP-1 protein expression. ARLEE treatment of cells at $12.5,25$, and $50 \mu \mathrm{g} / \mathrm{mL}$ reduced MMP1 protein expression by $31.2 \%(p<0.01), 32.2 \%(p<0.01)$, and $46.1 \%(p<0.01)$, respectively, compared to that in UVA-irradiated control cells (Fig. 6).

Effect of ARLEE on MMP-1 mRNA expression. ARLEE treatment of cells at $12.5,25,50$, and $100 \mu \mathrm{g} / \mathrm{mL}$ reduced MMP-1 mRNA expression in a dose-dependent manner by $12.4 \%(p<0.05), 15.3 \%(p<0.05), 29.6 \%(p<0.01)$, and $36.1 \%(p<0.01)$, respectively, compared to that in UVAirradiated control cells (Fig. 7).
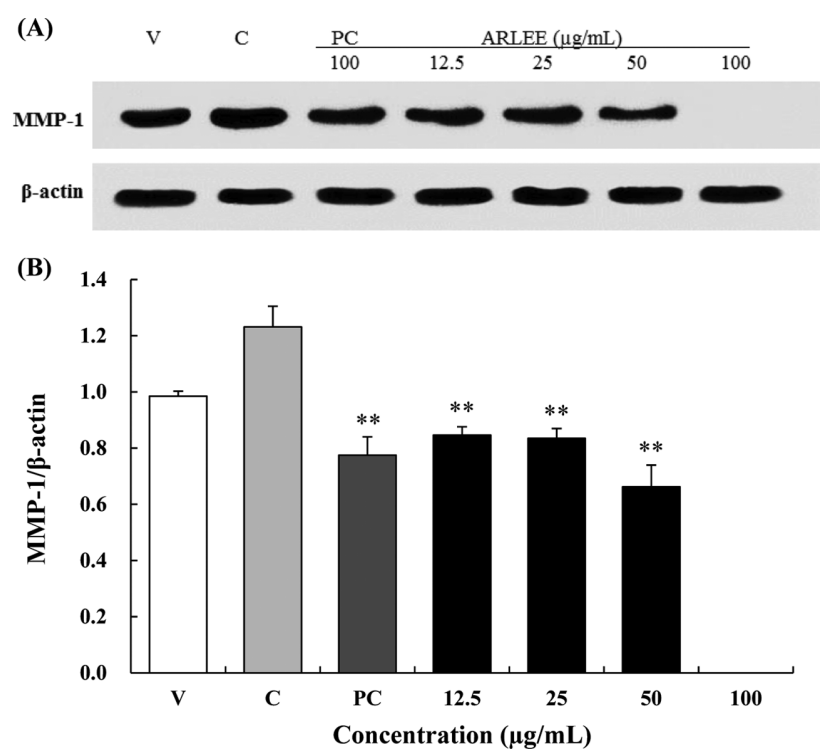

Fig. 6. Effect of ARLEE on MMP-1 protein expression in human dermal fibroblasts. (A) MMP-1 protein levels decreased upon treatment with $A$. rossii leaf ethanol extract (ARLEE) compared to UVA-irradiated control cells, as determined by western blotting. Expression was normalized to $\beta$-actin levels. (B) Quantification of MMP-1 protein expression in cells treated with vehicle $(\mathrm{V})$, $6.3 \mathrm{~J} / \mathrm{cm}^{2}$ UVA radiation (C), $6.3 \mathrm{~J} / \mathrm{cm}^{2}$ UVA radiation $+100 \mu \mathrm{g} / \mathrm{mL}$ ascorbic acid (PC), or $6.3 \mathrm{~J} / \mathrm{cm}^{2}$ UVA radiation + ARLEE at the indicated concentrations. Values are the mean $\pm S D$ of three independent measurements. The value with an asterisk is significantly different from the control group by Student's $t$-test (**; $p<0.01$ ). 

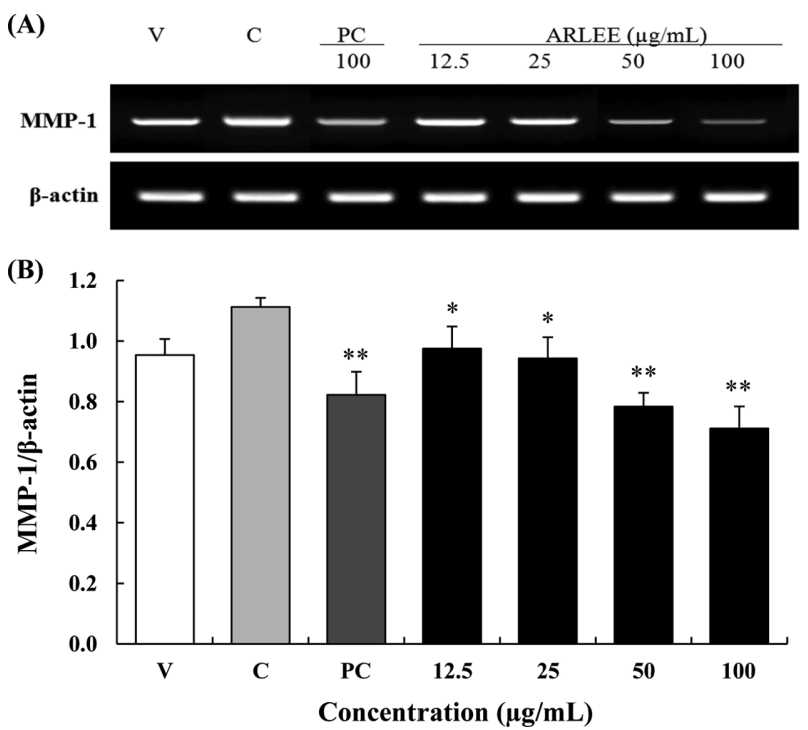

Fig. 7. Effect of ARLEE on MMP-1 mRNA expression in human dermal fibroblasts. (A) MMP-1 transcript levels decreased upon treatment with $A$. rossii leaf ethanol extract (ARLEE) in a dosedependent manner compared to UVA-irradiated control cells, as determined by RT-PCR. Expression was normalized to $\beta$-actin levels. (B) Quantification of MMP-1 transcript expression in cells treated with the vehicle $(\mathrm{V}), 6.3 \mathrm{~J} / \mathrm{cm}^{2}$ UVA radiation $(\mathrm{C}), 6.3 \mathrm{~J} /$ $\mathrm{cm}^{2}$ UVA radiation $+100 \mu \mathrm{g} / \mathrm{mL}$ ascorbic acid (PC), or $6.3 \mathrm{~J} / \mathrm{cm}^{2}$ UVA radiation + ARLEE at the indicated concentrations. Values are the mean \pm SD of three independent measurements. The value with an asterisk is significantly different from the control group by Student's $t$-test $\left({ }^{*} ; p<0.05,{ }^{* *} ; p<0.01\right.$ ).

\section{DISCUSSION}

Antioxidants protect against potentially damaging oxidative stress, which is a result of an imbalance between the formation of ROS and the body's antioxidant defense. UVA rays absorbed by the skin lead to the generation of ROS in dermal fibroblasts (20). ROS cause oxidative damage to major cellular components and play an important role in different molecular pathways (21).

Phenolic compounds are known to have antioxidant activity due to their capacity to scavenge free radicals and chelate metal ions, along with an ability to prevent free radical formation (22). The DPPH radical has been widely used as a model system to investigate the scavenging activities of several natural compounds including phenolic compounds, flavonoids, and crude mixtures such as ethanol or water extracts of plants (23). In this study, the leaves of $A$. rossii had much higher polyphenol and flavonoid contents than its stems and roots. Therefore, we used ARLEE to evaluate anti-wrinkle effects. The total polyphenol and flavonoid contents of ARLEE were 578.6 and $206.3 \mathrm{mg} / \mathrm{g}$, respectively. These values are higher than the values reported by Lim et al. (307.6 and $119.0 \mathrm{mg} / \mathrm{g}$, respectively) (13) and even higher than those for epigallocatechin gallate, a well- known antioxidant agent (435 and $180 \mathrm{mg} / \mathrm{g}$, respectively) (24). The electron-donating ability of ARLEE at 1,000 $\mu \mathrm{g} /$ $\mathrm{mL}$ was $88.7 \%$. Lim et al. reported its IC50 value at $549.9 \mu \mathrm{g} / \mathrm{mL}$ (13).

Fibroblasts play an important role in production of elastin, collagen, and ground substances such as glycosaminoglycans and proteoglycans (25). The reduction of collagen is either owing to a reduction in the synthetic activity of dermal fibroblasts or an increased rate of degradation by collagenase. Elastin, an insoluble fibrous protein, occupies only $2 \sim 4 \%$ of the dermis matrix, but plays an important role in maintaining the elasticity of the skin (26). In the current study, ARLEE $(1.25 \sim 10 \mathrm{mg} / \mathrm{mL})$ strikingly inhibited collagenase and elastase activity in a concentration-dependent manner, exhibiting $97.1 \%$ and $99.2 \%$ inhibition at $10 \mathrm{mg} /$ $\mathrm{mL}$, respectively, even better than those of ascorbic acid $(100.0 \%$ and $51.6 \%)$.

UV irradiation impairs ongoing collagen synthesis, primarily through the down-regulation of type 1 procollagen expression (27). MMP-1 is primarily responsible for dermal collagen degradation during the process of skin aging. In this study, levels of carboxy-terminal propeptide of type I procollagen were measured in the medium as a marker of extracellular type I collagen synthesis. In the present investigation of type-I procollagen synthetic ability using human dermal fibroblasts, ARLEE treatment at $100 \mu \mathrm{g} / \mathrm{mL}$ significantly $(p<0.01)$ increased type-I procollagen synthesis by $50.7 \%$ in comparison with the vehicle control. In addition, ARLEE treatment at $12.5 \sim 100 \mu \mathrm{g} / \mathrm{mL}$ significantly decreased the protein and mRNA expression levels of MMP-1 in a dose-dependent manner $(p<0.05$ or $p<0.01)$.

In conclusion, our study demonstrated that ARLEE strikingly inhibits collagenase and elastase activity, and has high efficacy in the promotion of collagen synthesis and in the inhibition of its degradation in human dermal fibroblasts, even superior to those of ascorbic acid. The potential mechanism of action underlying the anti-wrinkle effects of ARLEE is hypothesized to be due to its outstandingly high contents of phenolic compounds that can scavenge free radicals and prevent free radical formation, along with its ability to chelate MMPs induced by UV rays. Thus, ARLEE could be a useful functional cosmetic in the prevention or alleviation of skin-wrinkling induced by UV rays.

\section{REFERENCES}

1. Jenkins, G. (2002) Molecular mechanisms of skin aging. Mech. Ageing Dev., 123, 801-810.

2. Berneburg, M., Plettenberg, H. and Krutmann, J. (2000) Photoaging of human skin. Photodermatol. Photoimmunol. Photomed., 16, 239-244.

3. Di Lullo, G.A., Sweeney, S.M., Körkkö, J., Ala-Kokko, L. and San Antonio, J.D. (2002) Mapping the ligand-binding sites and disease-associated mutations on the most abundant protein in the human, type I collagen. J. Biol. Chem., 277, 4223- 
4231.

4. Chambers, A.F. and Matrisian, L.M. (1997) Changing views of the role of matrix metalloproteinases in metastasis. J. Natl. Cancer Inst., 89, 1260-1270.

5. Welgus, H.G., Campbell, E.J., Cury, J.D., Eisen, A.Z., Senior, R.M., Wilhelm, S.M. and Goldberg, G.I. (1990) Neutral metalloproteinases produced by human mononuclear phagocytes. Enzyme profile, regulation, and expression during cellular development. J. Clin. Invest., 86, 1496-1502.

6. Offord, E.A., Gautier, J.C., Avanti, O., Scaletta, C., Runge, F., Krämer, K. and Applegate, L.A. (2002) Photoprotective potential of lycopene, $\beta$-carotene, vitamin $\mathrm{E}$, vitamin $\mathrm{C}$ and carnosic acid in UVA-irradiated human skin fibroblasts. Free Radical Biol. Med., 32, 1293-1303.

7. Ivanov, V., Ivanova, S., Roomi, M.W., Kalinovsky, T., Niedzwiecki, A. and Rath, M. (2007) Extracellular matrix-mediated control of aortic smooth muscle cell growth and migration by a combination of ascorbic acid, lysine, proline, and catechins. J. Cardiovasc. Pharmacol., 50, 541-547.

8. Choi, C.P., Kim, Y.I., Lee, J.W. and Lee, M.H. (2007) The effect of narrowband ultraviolet $\mathrm{B}$ on the expression of matrix metalloproteinase-1, transforming growth factor-betal and type I collagen in human skin fibroblasts. Clin. Exp. Dermatol., 32, 180-185.

9. Chen, C.L., Liou, S.F., Chen, S.J. and Shih, M.F. (2011) Protective effects of chlorella-derived peptide on UVB-induced production of MMP-1 and degradation of procollagen genes in human skin fibroblasts. Regul. Toxicol. Pharmacol., 60, 112-119.

10. Matrisian, L.M., Ganser, G.L., Kerr, L.D., Pelton, R.W. and Wood, L.D. (1992) Negative regulation of gene expression by TGF-beta. Mol. Reprod. Dev., 32, 111-120.

11. Han, J.T., Kim, H.Y., Park, Y.D., Lee, Y.H., Lee, K.R., Kwon, B.M. and Baek, N.I. (2002) Aceriphyllic acid A, a new ACAT inhibitory triterpenoid, from Aceriphyllum rossii. Planta Med., 68, 558-561.

12. Ahn, E.M., Han, J.T., Kwon, B.M., Kim, S.H. and Baek, N.I. (2008) Anti-cancer activity of flavonoids from Aceriphyllum rossii. J. Korean Soc. Appl. Biol. Chem., 51, 309-315.

13. Lim, S.H., Kim, H.Y., Park, M.H., Park, Y.H., Ham, H.J., Lee, K.Y., Kim, K.H., Park, D.S. and Kim, S.M. (2010) Biological activities of solvent extracts from leaves of Aceriphyllum rossii. J. Korean Soc. Food Sci. Nutr., 39, 1739-1744.

14. Middleton, E. Jr. and Drzewiecki, G. (1984) Flavonoid inhibition of human basophil histamine release stimulated by vari- ous agents. Biochem. Pharmacol., 33, 3333-3338.

15. Folin, O. and Denis, W. (1912) On phosphotungstic-phosphomolybdic compounds as color reagents. J. Biol. Chem., 12, 239-243.

16. Davies, R., Massey, R.C. and McWeeny, D.J. (1980) The catalysis of the N-nitrosation of secondary amines by nitrosophenols. Food Chem., 6, 115-122.

17. Blois, M.S. (1958) Antioxidant determinations by the use of a stable free radical. Nature, 181, 1199-1200.

18. Son, E.D., Choi, G.H., Kim, H., Lee, B., Chang, I.S. and Hwang, J.S. (2007) Alpha-ketoglutarate stimulates procollagen production in cultured human dermal fibroblasts, and decreases UVB-induced wrinkle formation following topical application on the dorsal skin of hairless mice. Biol. Pharm. Bull., 30, 1395-1399.

19. Lowry, O.H., Rosebrough, N.J., Farr, A.L. and Randall, R.J. (1951) Protein measurement with the Folin phenol reagent. $J$. Biol. Chem., 193, 265-275.

20. Wondrak, G.T., Roberts, M.J., Cervantes-Laurean, D., Jacobson, M.K. and Jacobson, E.L. (2003) Proteins of the extracellular matrix are sensitizers of photo-oxidative stress in human skin cells. J. Invest. Dermatol., 121, 578-586.

21. Bickers, D.R. and Athar, M. (2006) Oxidative stress in the pathogenesis of skin disease. J. Invest. Dermatol., 126, 25652575.

22. Seyoum, A., Asres, K. and El-Fiky, F.K. (2006) Structure-radical scavenging activity relationships of flavonoids. Phytochemistry, 67, 2058-2070.

23. Chang, H.C., Huang, G.J., Agrawal, D.C., Kuo, C.L., Wu, C.R. and Tsay, H.S. (2007) Antioxidant activities and polyphenol contents of six folk medicinal ferns used as "Gusuibu". Bot. Stud., 48, 397-406.

24. Kim, Y.C., Choi, S.Y. and Park, E.Y. (2015) Anti-melanogenic effects of black, green, and white tea extracts on immortalized melanocytes. J. Vet. Sci., 16, 135-143.

25. Kondo, S. (2000) The roles of cytokines in photoaging. $J$. Dermatol. Sci., 23 Suppl 1, S30-36.

26. Godeau, G. and Hornebeck, W. (1988) Morphometric analysis of the degradation of human skin elastic fibers by human leukocyte elastase (EC 3-4-21-37) and human skin fibroblast elastase (EC 3-4-24). Pathol. Biol., 36, 1133-1138.

27. Fisher, G.J., Kang, S., Varani, J., Bata-Csorgo, Z., Wan, Y., Datta, S. and Voorhees, J.J. (2002) Mechanisms of photoaging and chronological skin aging. Arch. Dermatol., 138, $1462-1470$. 